\title{
VFA Concentration, Ammonia And pH Value In Vivo Ransum Rument System Made From Rice Fermentation of Lamtoro Leaves, Gamal Leaves And Indigofera Leaves
}

\author{
Abdul Hakim Fattah 1,2, Jasmal A. Syamsu ${ }^{3}$, A. Natsir ${ }^{3}$, Syamsuddin Garantjang4 \\ ${ }^{1}$ Animal Husbandry Study Program, Muhammadiyah School of Agriculture (STIP Muhammadiyah), Sinjai, Indonesia (92611) \\ ${ }^{2}$ Postgraduate School, Hasanuddin University, Makassar, Indonesia (90245) \\ ${ }^{3}$ Animal Nutrition Department, Faculty of Animal of Science, Hasanuddin University, Makassar, Indonesia 90245 \\ ${ }^{4}$ Animal Production Department, Faculty of Animal of Science, Hasanuddin University, Makassar, Indonesia 90245
}

Corresponding Author: Abdul Hakim Fattah. Animal Husbandry Study Program, Muhammadiyah School of Agriculture (STIP Muhammadiyah), Sinjai, Indonesia (92611)

E-mail: hakimabdulfattah@gmail.com

Received date: 28 August 2019, Accepted date: 12 December 2019, Online date: 20 December 2019

Copyright: (C) 2019 Abdul Hakim Fattah et al., This is an open-access article distributed under the terms of the Creative Commons Attribution License, which permits unrestricted use, distribution, and reproduction in any medium, provided the original author and source are credited.

\begin{abstract}
The use of rice straw directly as a single feed cannot meet the supply of nutrients needed by livestock, so it needs to be substituted with high-quality concentrate feed ingredients sourced from legume crops namely lamtoro, gamal and indigofera. The purpose of this study was to determine the value of the concentration of VFA, Ammonia and pH value. The study design used was a Randomized Block Design with 3 kinds of dairy feed supplement as a treatment, with 3 replications. Each treatment was P1 = Fermented Rice Straw (70\%) + Lamtoro (30\%) P2 = Fermented Rice Straw (70\%) + Gamal 30\%, P3 = Fermented Rice Straw $(\mathbf{7 0} \%)$ + Indigofera $(30 \%)$. The parameters observed were VFA concentration, Ammonia, and pH value. The results showed no significant difference between treatments $(P>0.05)$. P1 treatment was not significantly different from P2 treatment and P3 treatment. The range of VFA concentrations produced was 89.05 to $91.39 \mathrm{mM}$ with the highest VFA values in the P3 treatment and the lowest in the P2 treatment. The range of In Vivo rumen ammonia concentrations produced is between $4.49 \mathrm{mM}$ to $4.55 \mathrm{mM}$. The $\mathrm{pH}$ range in this study was 6.97 to 7.21 . This study concludes that the combination of fermented rice straw-based feed with the combination of lamtoro leaf, gamal leaf and indigofera leaves produced shows rumen conditions that are suitable for rumen microbial growth.
\end{abstract}

Keywords: fermented rice straw, Gamal leaf, lamtoro leaf, Indigofera leaf VFA concentration, ammonia, pH, in vivo.

\section{INTRODUCTION}

The Rice straw is the most potential agricultural waste among other agricultural wastes because the quantity is high and the availability exceeds the amount needed by ruminants but the use of rice straw as feed has limiting factors, namely high crude fiber and low nitrogen content [1]. High crude fiber inhibits the process of hydrolysis by microbial enzymes in the rumen, thereby reducing the level of digestion [2]. The digestibility value of dry ingredients of rice straw only reaches $35-37 \%$ and the crude protein content is only about 3-4\%, even though ruminants require feed foraged ingredients with a minimum digestibility value of 50-55\% and crude protein content of about $8 \%$ [3]. The results of the research on the crude protein content of rice straw in Indonesia also showed varied results. Rice straw from South Sulawesi contains crude protein of 4.31\%. [4], Aceh 4.90\%. [5], Mataram, Lombok 4.74\%. [6], Bali 3.45\% [7].

The low protein content of crude rice straw, it is necessary to increase efficiency through an appropriate feed technology. One of the appropriate feed technologies used in the processing of animal feed ingredients is biological processing to improve the digestibility of feed. However, the use of rice straw directly as a single feed cannot meet the supply of nutrients needed by livestock, so it needs to be substituted with high-quality concentrate feed ingredients sourced from legume crops namely lamtoro, gamal and Indigofera.

Ruminant livestock feed mostly consists of forages containing structural carbohydrates in the form of crude fiber (cellulose and hemicellulose) and non-fermentable non-structural carbohydrates (sugar and starch), both of which will be fermented into flying fatty acids, [8]. Flying fatty acids can be used for the growth of rumen microorganisms which help digest crude fibers in the rumen as well as a source of carbon skeletons for the formation of microbial proteins [9]. The combination of Leguminosae Indigofera falcata and rice straw that is $62 \%: 38 \%$ (100\% forage), can meet the nutritional needs needed by dairy cows for basic living and production. Fiber feed (forage source) will produce more acetate than propionate so it is more suitable for livestock 
raised for milk production. A relatively high or low Flying fatty acids concentration shows a fermentation pattern that is seen in the forage feed but is less visible in the concentrate feed [10]. Total Flying fatty acids concentrations suitable for livestock survival are 70-150 $\mathrm{mM}$ [11]. With its optimum point is $110 \mathrm{mM}$ [12].

Ammonia $\left(\mathrm{NH}_{3}\right)$ is the result of the metabolism of protein and non-protein nitrogen. High protein availability from legumes will cause microbial growth in the rumen to grow optimally because the result of degradation of feed protein by rumen microbes in addition to producing high $\mathrm{NH}_{3}$ concentrations will also be a food source for microbes in the rumen for growth and development along with the carbon framework produced by Flying fatty acids into protein microbial [13].

Based on this background of thought it is necessary to study the combination of fermented rice straw with lamtoro leaves, gamal leaves and indigofera leaves to increase the value of VFA, Ammonia and $\mathrm{pH}$ values. The purpose of this study was to determine the value of the concentration of VFA, Ammonia and $\mathrm{pH}$ value

\subsection{Research design}

\section{RESEARCH MATERIALS AND METHODS}

The experiment design was randomized block design [14] which consisted of 3 treatments and 3 replications with the structure of the treatment being:

P1: Fermented Rice Straw (70\%) + Gamal 30\%

P2: Fermented Rice Straw (70\%) + Lamtoro 30\%

P3: Fermented Rice Straw (70\%) + Indigofera 30\%

\subsection{Implementation}

\subsubsection{Maintenance}

Twelve cattle were divided into three treatments and each treatment had three replications. Cattle are kept in individual cages for ten weeks. The first two weeks are used as the feed adaptation period (preliminary) and in the third to tenth-week observations are made. Feeding $2.5-3 \%$ of body weight is done twice a day, in the morning at $06.00-07.00$ WIB and in the afternoon at 16.00 - 17.00 WIB. A feed is given by mixing fermented rice straw with forage concentrates while providing drinking water in an ad libitum manner.

\subsubsection{Intake of rumen fluid}

Intake of rumen fluid is carried out in the last week of the treatment stage after meals. Intake of rumen fluid is taken using a vacuum pump that is by using a small hose that is inserted into the rumen of a cow (stomach tube) through the mouth of cattle.

\subsection{Research Parameters}

Parameters observed during the study included $\mathrm{pH}$ with a $\mathrm{pH}$ meter, $\mathrm{NH}_{3}$ with the Conway Microdifusion method (General Laboratory 1966) and total VFA with the Steam Distillation Technique (General Laboratory Procedure, Department of Dairy Science University of Wisconsin 1969)

\subsection{1 pH value}

The rumen $\mathrm{pH}$ value is measured on a sample that has been incubated for 4 hours. The $\mathrm{pH}$ value was measured using a $\mathrm{pH}$ meter after the tube was removed from the water bath shaker and before it was dropped with $\mathrm{HgCl}_{2}$

Determination of $\mathrm{N}-\mathrm{NH}_{3}$ Levels in Rumen Fluids

$\mathrm{NH} 3=(\mathrm{ml}$ titration $\mathrm{x}$ N H2SO $4 \times 1000) \mathrm{mM}$

2.3.2 Measurement of VFA

VFA concentration $($ total $\mathrm{mM})=\frac{(\mathrm{a}-\mathrm{b}) \mathrm{x} \mathrm{NHCl} \times \frac{1000}{5} \mathrm{ml}}{\text { Sample weight } \mathrm{x} \% \text { BK Ration }}$

\subsection{Data analysis}

Data were analyzed using analysis of variance based on randomized block design. To see the effect of differences in each treatment then Duncan's distance test [14].

\subsection{Results}

\section{RESULTS AND DISCUSSION}

Average VFA concentrations, rumen ammonia and $\mathrm{pH}$ values, In Vivo rations made from Fermented rice straw, gamal, lamtoro and Indigofera can be seen in Table $1 .$.

Table 1. Concentrations of VFA, Ammonia Rumen and $\mathrm{pH}$ Value, In Vivo

\begin{tabular}{|l|l|l|l|}
\hline Treatment & $\mathbf{P}_{\mathbf{1}}$ & $\mathbf{P}_{\mathbf{2}}$ & $\mathbf{P}_{\mathbf{3}}$ \\
\hline VFA $(\mathrm{mM})$ & $91,25 \pm 2,84$ & $89,05 \pm 0,3$ & $91,39 \pm 2,37$ \\
\hline Amonia $(\mathrm{mM})$ & $4,55 \pm 0,05$ & $4,49 \pm 0,07$ & $4,54 \pm 0,04$ \\
\hline $\mathrm{pH}$ & $7,21 \pm 0,24$ & $6,97 \pm 0,16$ & $7,03 \pm 0,54$ \\
\hline
\end{tabular}

P1: 70\% Fermented rice straw $+30 \%$ lamtoro leaf; P2: 70\% Fermented rice straw $+30 \%$ gamal leaf P3: 70\% Fermented rice straw $+30 \%$ Indigofera leaf). 
Citation: Abdul Hakim Fattah et al., 2019. VFA Concentration, Ammonia And pH Value In Vivo Ransum Rument System Made From Rice Fermentation Of Lamtoro Leaves, Gamal Leaves And Indigofera Leaves. Advances in Environmental Biology., 13(12): 4-9. DOI:10.22587/aeb.2019.13.12.2

The results of variance showed that the treatment was not significantly different $(\mathrm{P}>0.05)$ in VFA concentration, ammonia concentration and $\mathrm{pH}$ value in feed made from fermented rice straw, gamal, lamtoro and Indigofera.

\subsection{DISCUSSION}

\subsubsection{VFA concentration}

Further test results showed that the concentration of VFA produced was not significantly different $(\mathrm{P}>0.05)$ between treatments. The highest VFA value in the P3 treatment and the lowest in the P2 treatment. The concentration of VFA needed for an animal to grow normally is around $80-160 \mathrm{mM}$. [12] In this study, the range of VFA concentrations produced was between 89.05 to $91.39 \mathrm{mM}$ or within the normal range to support rumen microbial growth. The results of other studies obtained VFA concentrations in the range of 70 to $130 \mathrm{mM} / \mathrm{L}$. [15]. VFA concentrations in this study still meet the standards for rumen microbial breeding

This shows that there is a difference in the total VFA that is affected by different feeds so that the feed nutrients consumed differ. The VFA concentration of the rumen of dairy cows given different feeding treatments is presented in Figure 1

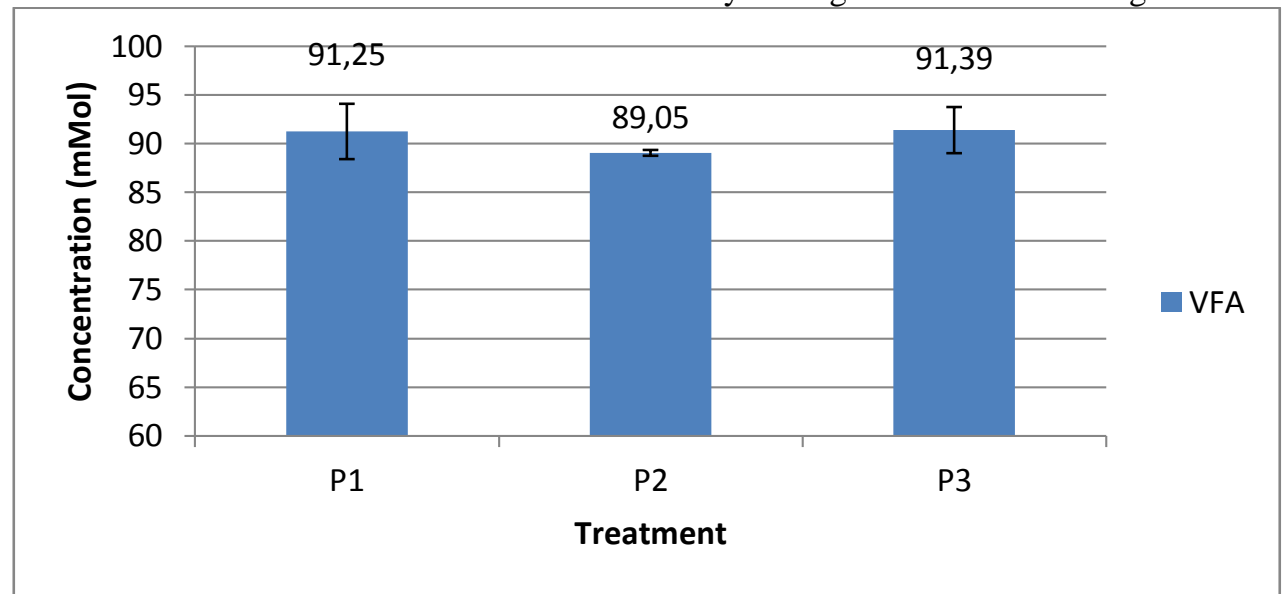

Figure 1. Graph of Rumen In Vivo VFA Concentration.

P1: 70\% Fermented rice straw $+30 \%$ lamtoro leaf; P2: 70\% Fermented rice straw $+30 \%$ gamal leaf P3: 70\% Fermented rice straw $+30 \%$ Indigofera leaf)

VFA concentrations generally range from 70-150 mM. Total VFA concentrations can drop to $30 \mathrm{mM}$ or increase to $200 \mathrm{mM}$, but generally, VFA concentrations range from 70 to $130 \mathrm{mM}$. VFA production depends on the food consumed, as well as the relative proportion of acids produced. In the provision of high forages, the proportion of acetate increases, whereas in the provision of high concentrates the proportion of propionate will increase [11].

Fermentation of feed in the rumen is the largest source of $\mathrm{CH} 4$ producers, most of the percentage of molar per VFA produced during fermentation affects the production of $\mathrm{CH} 4$ in the rumen. [16] other studies with the addition of S. cerevisiae to the acetate: propionate ratio had no significant effect. However, the use of legume mixture tends to have smaller concentrations compared to concentrates [17].

Theoretically, an increase in TDN in the ration can improve the production of rumen fluid VFA which can be described by the high total VFA concentration [18]. The higher the organic matter content of the feed, the more BO is fermented in the rumen. But the findings of this study do not illustrate an increase in VFA production. This is allegedly due to the consumption of feed in the same three treatments. Most of the carbohydrate compounds in a feed (starch, cellulose, hemicellulose, and pectin) are fermented by rumen microbes and converted to VFA, so that VFA production will increase. Most of the concentrates are nonstructural carbohydrates. Digestion of non-structural carbohydrates in the rumen is easier and faster than structural carbohydrates, so non-structural carbohydrates contribute to higher VFA production [8]. The increase in partial VFA concentrations in legume mixtures is thought to be due to the bioactive and secondary compounds they contain. Bioactive and secondary compounds in legume mixtures have a positive effect in increasing total VFA and propionate [19]

\subsubsection{Concentration of Ammonia Rumen In Vivo}

NH3 is the result of the overhaul of feed protein into peptides and amino acids by rumen microbes and the hydrolysis of urea Ammonia $\left(\mathrm{NH}_{3}\right)$ is one of the parameters that can be measured to determine the availability of $\mathrm{N}$ sources in the rumen. The smaller the $\mathrm{NH}_{3}$ value, the higher the microbial protein synthesis. [20]

Further test results showed that the concentration of ammonia produced was not significantly different $(\mathrm{P}>0.05)$ between treatments. The range of In Vivo rumen ammonia concentrations produced is between $4.49 \mathrm{mM}$ to $4.55 \mathrm{mM}$. The ration that produces the highest concentration of In Vivo rumen ammonia will guarantee the growth of microbes present in the rumen. Fermentation will reduce feed degradation because it can loosen bonds between cell wall components, thus reducing rumen ammonia concentration. Protein-deficient feeds or degradable resistant proteins have low ammonia concentrations in the rumen 
and rumen microbial growth will be slow which leads to increased digestibility of feed [11]. The concentration of ammonia rumen of dairy cows given different feeding treatments is presented in Figure 2.

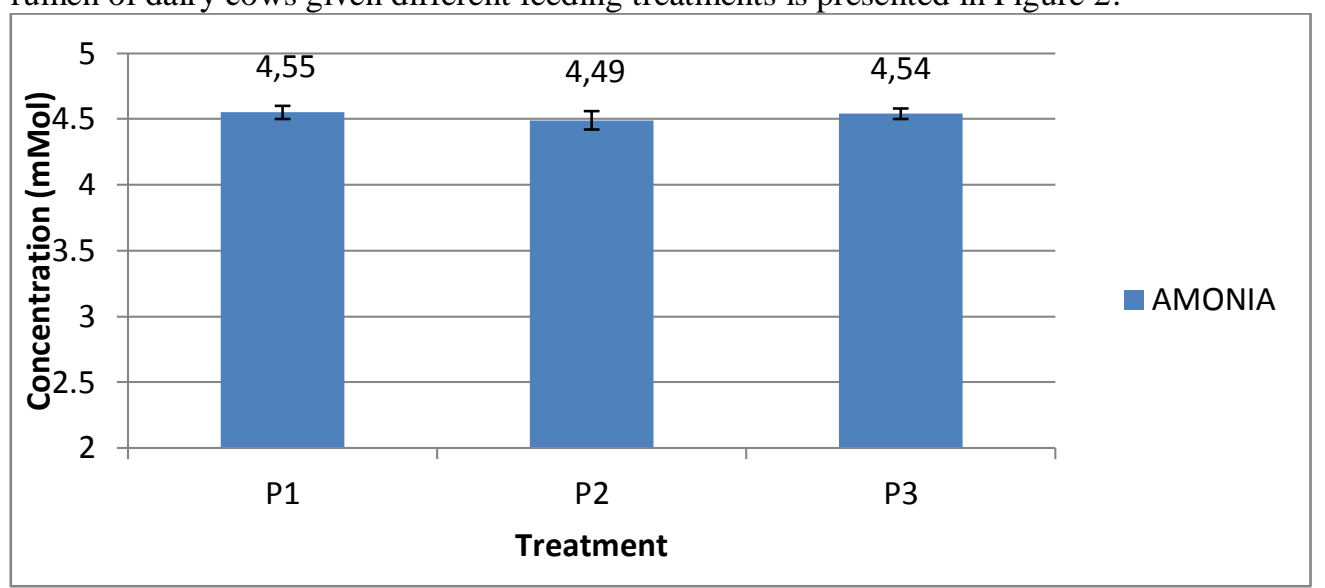

Figure 2. Graph of Rumen In Vivo Ammonia Concentration.

P1: 70\% Fermented rice straw $+30 \%$ lamtoro leaf; P2: 70\% Fermented rice straw $+30 \%$ gamal leaf P3: 70\% Fermented rice straw $+30 \%$ Indigofera leaf).

Synthesis of rumen microbial protein will be maximal if supported by ammonia concentrations of 4 to $12 \mathrm{mM}^{\text {. [21] } \mathrm{NH}_{3}}$ production in addition to being determined by crude protein content is also influenced by the degradability of crude protein. [18] The increase in NH3 production is in line with the increasing number of microbial populations in the rumen due to the high le vel of degradation of hibiscus leaves. [22] Feed ingredients that have crude protein (PK) content of $10.56 \%$ will produce ammonia (NH3) levels of $3.60-3.73 \mathrm{mM}$. This indicates that the results of ammonia levels are determined by the size of the crude protein content in feed ingredients[23].

High or low concentration of $\mathrm{NH}_{3}$ is influenced by the amount of degradation of crude protein $(\mathrm{PK})$ in the rumen. $\mathrm{NH}_{3}$ concentration increases if the level of PK degradation in the rumen is high, but if the level of PK degradation in the rumen is low then the resulting NH 3 concentration is also low. Microbes can work optimally to remodel amino acids which are then used to make their body's proteins [24].

Protein degradation in the rumen through the breakdown of proteins, oligopeptides, dipeptides, amino acids and the end product of ammonia. The process of degradation of amino acids into ammonia occurs inside microbial cells, while the process of degradation of proteins into amino acids occurs outside the cell [25]. The proportion of feed protein that supports the growth of rumen and livestock microbes consists of easily degraded proteins of $70 \%-80 \%$ and $30 \%-40 \%$ in the form of proteins that are more difficult to degrade. Ammonia in the rumen is a source of $\mathrm{N}$ for microbial protein synthesis [11]. Ammonia levels are influenced by fermented carbohydrate levels, this is because the higher energy content will make bacteria use more ammonia to synthesize bacterial proteins than those released [26].

\subsection{3 pH of the Rumen In Vivo}

The degree of acidity $(\mathrm{pH})$ of the rumen fluid needs to be measured to obtain information about conditions in the rumen. The $\mathrm{pH}$ value determines the condition of the rumen, affects the growth of rumen microbes and rumen fermented products.

When fermenting in the rumen, acid is produced thereby reducing the $\mathrm{pH}$ of the rumen fluid below 5.5, but under normal conditions, the $\mathrm{pH}$ is maintained at 5.5-6.5 [11]. Low rumen $\mathrm{pH}$ can occur when given high feed concentrates. The decrease in $\mathrm{pH}$ occurs at the same time as the amount of concentrate feed increases. Changes in rumen fermentation are thought to be caused by the $\mathrm{pH}$ and type of fermented substrate [27]. The effect of low $\mathrm{pH}$ on rumen microbial fermentation also depends on the magnitude of the decrease in $\mathrm{pH}[28]$.

Further test results showed that the $\mathrm{pH}$ value produced was not significantly different $(\mathrm{P}>0.05)$ between treatments. The $\mathrm{pH}$ range in this study was 6.97 to 7.21 . With the highest $\mathrm{pH}$ value at treatment $\mathrm{P} 1$ and lowest at treatment $\mathrm{P} 2$. The rumen $\mathrm{pH}$ concentration of dairy cows given different feeding treatments is presented in Figure 3 


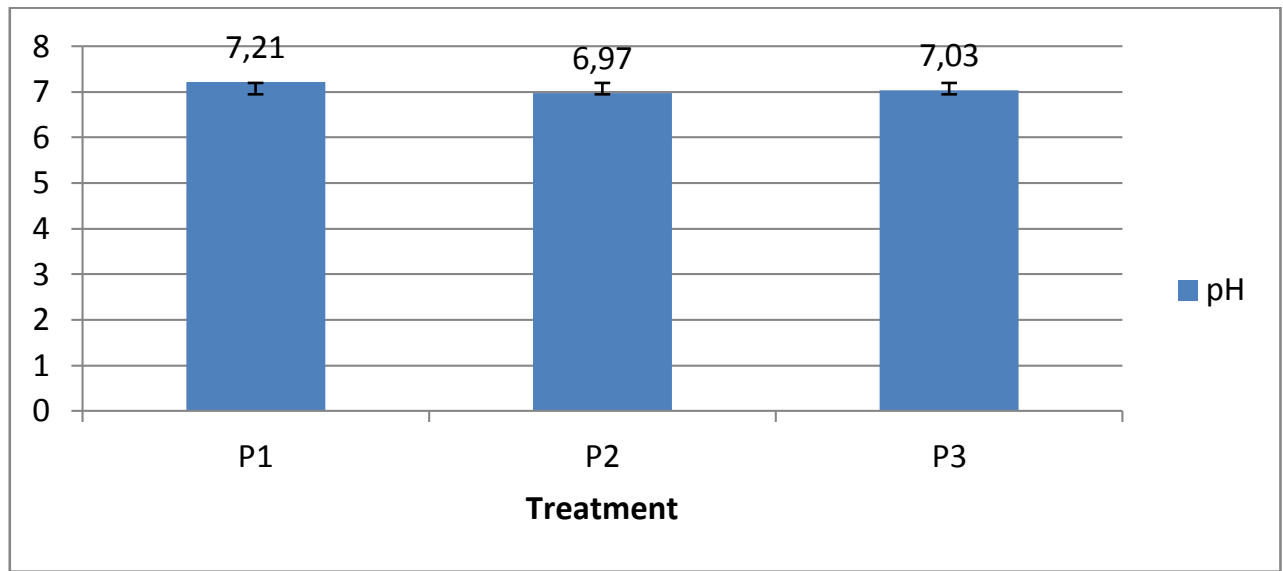

Figure 3. Rumen In Vivo pH chart.

P1: 70\% Fermented rice straw $+30 \%$ lamtoro leaf; P2: $70 \%$ Fermented rice straw + 30\% gamal leaf P3: 70\% Fermented rice straw $+30 \%$ Indigofera leaf).

The resulting rumen $\mathrm{pH}$ value indicates rumen conditions that are suitable or not suitable for rumen microbial growth. Variance analysis results showed that the treatment of fermented rice straw with the substitution of green concentrate did not affect the rumen $\mathrm{pH}$ value. The $\mathrm{pH}$ value is almost the same for each treatment indicating that the three treatments do not interfere with rumen fermentation activity. The $\mathrm{pH}$ range of the rumen fluid obtained was $6.97-7.21$, still in the pH range of $5.5-7.2$ [29]. The average $\mathrm{pH}$ of bovine rumen fluid in $\mathrm{PFH}$ in this study is still in the normal $\mathrm{pH}$ range so that the activity of cellulolytic bacteria is not inhibited. Cellulolytic bacterial activity is inhibited if the $\mathrm{pH}$ of the rumen fluid is below 6.2 and the activity will be optimal in the rumen at a $\mathrm{pH}$ of 6.7 [0.5 points [8]. However, the $\mathrm{pH}$ value obtained in this study is still within the normal range. Cellulolytic bacteria require a rumen $\mathrm{pH}$ of around 6.2-7.0 to develop rapidly. [30] The normal $\mathrm{pH}$ of the rumen is around 5.5-7.0 with a normal feed ratio. The actual $\mathrm{pH}$ value describes the amount of acid produced by microflora in the rumen. The minimum $\mathrm{pH}$ value is generally achieved around 2-6 hours after a meal, according to maximum acid production. The change in $\mathrm{pH}$ is influenced by the time after eating, the nature of the feed, and the frequency of feeding animals [31].

\section{CONCLUSIONS}

Based on the VFA concentration values, Ammonia and $\mathrm{pH}$ value of feed made from fermented rice straw with supplementation of lamtoro leaves, gamal leaves and indigofera leaves produced showed suitable rumen conditions for rumen microbial growth.

\section{Acknowledgement}

The author would like to thank the graduate of Hasanuddin University for funding this research and also to Mr Syahrul from the chemical laboratory and animal feed at the Faculty of Animal Husbandry for helping to analyze this VFA, Ammonia and pH research

\section{REFERENCES}

[1] Weimer, P.J., D.R. Mertens, E. Ponnampalam, B.F.Severin and B.E. Dale. 2003. Fibex-treated rice Antonius. straw as a feed ingredient for lactating dairy cows. Anim. Feed Sci. Technol. 103: 41-50

[2] Tang, S.X., G.O. Tayo, Z.L. Tan, Z.H. Sun, L.X. Shen, C.S.Zhou, W.J. Xiao, G.P. Ren, X.F. Han and S.B. Shen. 2008. Effects of yeast culture and fibrolytic enzyme supplementation on in vitro fermentation characteristics of low-quality cereal straws. J. Anim. Sci. 86: 1164-1172.

[3] Thalib, A., Y. Widiawati, H. Hamid dan Mulyani. 2000. Identifikasi morfologis uji aktivitas mikroba rumen dari hewanhewan ruminansia yang telah teradaptasi pada substrat selulosa dan hemiselulosa. Prosiding Seminar Nasional Peternakan dan Veteriner. Bogor 18-19 September 2000. Pusat Penelitian Peternakan. Badan Penelitian dan Pengembangan Pertanian Departemen Pertanian. Bogor. hlm : 341-348

[4] Syamsu, J.A., Natsir, A., Siswadi., Abustam, E., Hikmah, Nurlaelah, Muliwarni, Setiawan, A.H., dan Arasy, A.M. 2006. Limbah Tanaman Pangan sebagai Sumber Pakan Ruminansia: Potensi dan Daya Dukung di Sulawesi Selatan. Makassar: Yayasan Citra Emulsi dan Dinas Peternakan Propinsi Sulawesi Selatan

[5] Hanum, Z., dan Usman, Y. 2011. Ana-lisis Proksimat Amoniasi Jerami Padi Dengan Penambahan Isi Rumen. Agripet, 11(1):39-45

[6] Amin, M., Hasan, S.D., Yanuarianto, O., and Iqbal, M. 2015. Pengaruh Lama Fermentasi Terhadap Kualitas Jerami Padi Amoniasi yang Ditambah Probiotik Bacil-lus Sp. Jurnal Ilmu dan Teknolo-gi Peternakan Indonesia, 1 (1) : 8 - 13. ISSN : 2460-6669 
Citation: Abdul Hakim Fattah et al., 2019. VFA Concentration, Ammonia And pH Value In Vivo Ransum Rument System Made From Rice Fermentation of Lamtoro Leaves, Gamal Leaves And Indigofera Leaves. Advances in Environmental Biology., 13(12): 4-9. DOI:10.22587/aeb.2019.13.12.2

[7]Trisnadewi, A. A. A. S., Sumardani, N. L. G., Tanama Putri, B. R. I, Cakra, G. L. O., dan Aryani. I G. A. I. 2011. Peningkatan Kualitas Jerami Padi Melalui Penerapan Teknologi Amoniasi Urea Se-bagai Pakan Sapi Berkualitas Di Desa Bebalang Kabupaten Bangli. Udayana Mengabdi 10 (2): 72 - 74 ISSN : 1412-0925

[8] Van Soest, P.J. 1994. Nutritional Ecology of The Ruminant. 2nd ed, publish by Cornell University Pers. Itacha and London

[9] Sakinah, D. 2005. Kajian Suplementasi Probiotik Bermineral Terhadap Produksi VFA, NH3, dan Kecernaan Zat Makanan pada Domba. Skripsi. Fakultas Peternakan. Institut Pertanian Bogor. Bogor.

[10] France J, Dijkstra . 2005. Volatile fatty acid production. Di dalam: Forbes JM and France J, editors. Quantitative Aspects of Ruminant Digestion and Metabolism. Wallingford: Cab International.

[11] McDonald, P., R. Edwards and J. Greenhalgh. 2002. AnimalNutrition. 6th Edition. New York

[12] Suryapratama, W. 1999. Efek Suplementasi Asam Lemak Volatil Bercabang dan Kapsul Lisin serta Treonin Terhadap Nutrisi Protein Sapi Holstein. Disertasi. Program pascasarjana, Institut Pertanian Bogor. Bogor.

[13] Preston dan T. R. Leng. 1987. Matching Ruminant Produktion System With Available Research in The Tropic. Penambul Books Armidale. New South Wates, Australia. Hal. 21-28

[14] Steel, R. G. D. dan J. H. Torrie. 1993. Prinsip dan Prosedur Statistik Suatu Pendekatan Biometrik. Gramedia. Jakarta

[15] Khampa, S., Wanapat, M., Wachirapakorn, C.,Nontaso, N. and Wattiaux, M., 2006. Effects of Urea Level and Sodium dlMalate in Concentrate Containing High Cassava Chip on RuminalFermentation Efficiency, Microbial Protein Syntesis in Lactating DairyCows Raised Under TropicalCondition. Asian-Aust. J. Anim Sci. 19: 837-844.

[16] Moss RA, Jouany JP, Newbold J. 2000. Methane Production by Ruminants: Its Contribution to Global Warming. Ann Zootech. 49: 231-253.

[17] Desnoyers M, Giger-Reverdin S, Bertin G, Duvaux-Ponter C, Sauvant D. 2009. Meta-analysis of the influence of Saccharomyces cerevisiae supplementation on ruminal parameters and milk production of ruminants. J Dairy Sci. 92:1620-1632.

[18] Arora, S.D. 1995. Pencernaan Mikroba pada ruminansia. Cetakan kedua. Gajah Mada University Press. Yogyakarta.

[19] Durmic Z, Blache D. 2012. Bioactive plant and plant products: Effects on animal function, health and welfare. J Anim Feed Sci Tech. 176: 150-162.

[20] Perry, TW, Culliston AE, Lowrey RS. 2003. Feeds and Feeding. 6th ed. New Jersey (US): Prentice Hall

[21] Muhtarudin dan Liman. 2006. Penentuan tingkat penggunaan mineral organic untuk memperbaiki bioproses rumen pada kambing secara in vitro.Jurnal Ilmu-ilmu Pertanian Indonesia 8: 132-140

[22] Putra, S. 2006. Pengaruh suplementasigensia defaunasi dan waktu inkubasi terhadap bahan kering, bahan organic terdegradasi, dan produks fermeentasi secara in vitro. Jurnal Produksi Ternak (Animal Production) 8: 121-130.

[23] Aswandi, C. I. Sutrisno, M. Arifn, dan A.Joelal. 2012. Efek complete feed bonggol berbagai varietas tanamanpisang terhadap pH, NH3 dan VFA pada kambing kacang. (Effect ofcomplete feed containing starch tubers of different varieties of banana plantson pH, NH3 and VFA of kacang goat).Agricultural Counselling College ofManokwari, Doctoral Program Animal

Sciences, University of Diponegoro.JITP. 2(2)

[24] Cahyani, R.D., L.K. Nuswantara dan A. Subrata. 2012. Pengaruh Proteksi Protein Tepung Kedelai dengan Tanin Daun Bakau Terhadap Kosentrasi Amonia, Undegraded Protein dan Protein Total Secara In Vitro. Animal Agriculture Journal. 1(1): 159-166

[25] Hvelplund T, Weisbjerg MR. 2000. In Situ Techniques for the Estimation of Protein Degradability and Postrumen Availability. In: Givens DI, Owen E, Axford RFE, Omed HM. Forage Evaluation in Ruminant Nutrition. Oxon (GB): CABI

[26] Givens DI, Owen E, Axford RFE, Omed HM. 2000. Forage Evaluation inRuminant Nutrition. Oxon (GB): CABI.

[27] Calsamiglia S, Cardozo PW, Ferret A, Bach A. 2008. Changes in rumen microbial fermentation are due to a combined effect of type of diet and pH. J Anim Sci. 86:702-711.

[28] Cerrato-Sánchez M, Calsamiglia S, Ferret A. 2008. Effect of the magnitude of the decrease of rumen pH on rumen fermentation in a dual-flow continuous culture system. J Anim Sci. 86:378-383.

[29] Owens, F.N. and A.L. Goestch. 1988. Ruminant fermentation. In : D.C. Church (Ed). The Ruminant Animal Physiology and Nutrition. A Reston Book Prentice Hall. Engewood Cliffs, New Jersey. Hal : 145 - 171

[30] Orskov, E.R. and M. Ryle. 1990. Energy Nutrition in Ruminant. Elsevier Applied Science. London.

[31] Dehority, B. A. 2004. Rumen Microbiology. Nottingham University Press,Nottingham 